\title{
Isolation and Characterization of Bacteriophages Against Aeromonas hydrophila Bacteria Causing Hemorrhagic Septicemia from Striped Catfish (Pangasianodon hypophthalmus)
}

\section{Tran Thu Thuy ${ }^{1}$, Luu Huynh Anh${ }^{2}$, Hua Thai Nhan ${ }^{3}$, Ly Thi Thu Lan and Nguyen Trong Ngu $^{1 *}$}

${ }^{1}$ Department of Veterinary Medicine, College of Agriculture, Can Tho University, Vietnam

${ }^{2}$ Department of Animal Science, College of Agriculture, Can Tho University, Vietnam ${ }^{3}$ Department of Coastal Aquaculture, College of Aquaculture and Fisheries, Can Tho University, Vietnam

${ }^{4}$ School of Agriculture and Aquaculture, Tra Vinh University, Vietnam

*Corresponding Author: Nguyen Trong Ngu, Department of Veterinary Medicine, College of Agriculture, Can Tho University, Vietnam.

DOI: $10.31080 /$ ASVS.2022.04.0276
Received: November 11, 2021

Published: December 10, 2021

(C) All rights are reserved by Nguyen Trong

Ngu., et al.

\begin{abstract}
This study was conducted to isolate and characterize the bacteriophages capable of lysing Aeromonas hydrophila causing hemorrhagic septicemia in striped catfish (Pangasianodon hypophthalmus). The isolation and characterization were conducted in various samples of water, sludge, intestines and kidneys of animal. It was shown that, a total of 64 bacteriophages (58.2\%) were isolated from 110 samples, with the highest value being from sludge samples $(100 \%)$. When phages were tested in different $\mathrm{pH}$ levels $(2-$ 10 ), the above 64 phages were well adjusted to the $\mathrm{pH} 5-8$ after 24 hours at $28^{\circ} \mathrm{C}$, representing a rate of more than $60 \%$. In addition, in one hour, $50 \%$ of the phages could survive at different temperatures $\left(4^{\circ} \mathrm{C}, 20^{\circ} \mathrm{C}, 60^{\circ} \mathrm{C}, 80^{\circ} \mathrm{C}, 100^{\circ} \mathrm{C}\right.$, and $\left.120^{\circ} \mathrm{C}\right)$ with no effects on phages observed at $4^{\circ} \mathrm{C}$ and $20^{\circ} \mathrm{C}$. From the $\mathrm{pH}$ and temperature tests, six phages (B.N26, B.N16, B.R18, B.B8, B.R22, and B.N1) were selected to evaluate the lysis capacity against $A$. hydrophila in tap and river water for 21 days in vitro. The results revealed that the bacteriophages could survive better in river water than in tap water. All six phages could be utilized to investigate the effectiveness of treating A. hydrophila-caused hemorrhagic disease in catfish in vivo.
\end{abstract}

Keywords: Aeromonas hydrophila; Bacteriophage; Isolation; pH; Striped Catfish; Temperature

\section{Introduction}

Over the years, the striped catfish farming industry has grown significantly, becoming one of the main export aquaculture products of Vietnam. However, the increasing level of intensification to meet the rising market demand has led to frequent epidemics and serious consequences. Specifically, the hemorrhagic disease caused by Aeromonas hydrophila bacteria is one of the common diseases and causes significant damage to striped catfish farming in the Mekong Delta in Vietnam. In response to epidemics, antibiotic treatment has been a quick and effective method, but its improper and uncontrolled use increased drug resistance [1].
Many applications have been made to overcome these issues. Researchers have been looking for biological alternatives to antibiotics in disease treatment to prevent bacterial drug resistance and improve disease control. Among potential approaches, bacteriophage therapy is considered an effective alternative and provides a safe and sustainable method for farmers and consumers [2]. Previously, Jun., et al. [3] successfully isolated two bacteriophages that inhibited and treated diseases caused by $A$. hydrophila bacteria in fish. Easwaran., et al. [4] isolated a Myoviridae bacteriophage not only capable of lysing $A$. hydrophila causing disease in zebrafish but also having high stability when tested for temperature, $\mathrm{pH}$, and ion resistance as well. Recently, Akmal., et al. [5] isolated and 
characterized the Akh-2 bacteriophage, controlling Aeromonas in fish samples from Geoje Island in Korea. In Vietnam, Le., et al. [6] isolated two bacteriophages, namely $A$. hydrophila-phage 2 and $A$. hydrophila-phage 5 , from water samples from the Saigon River in Ho Chi Minh city. However, until now, research on the use of bacteriophages in aquaculture in Vietnam has been limited. Therefore, the current study was undertaken to isolate and characterize bacteriophages against $A$. hydrophila causing hemorrhagic septicemia in striped catfish, which could be used to replace antibiotics in treating this disease.

\section{Materials and Methods}

\section{Sample collection}

A total of 110 samples were collected, including water (30 samples) and sludge (11 samples) in the culturing ponds, as well as intestines (23 samples), livers (23 samples), and kidneys (23 samples) from fish in Chau Thanh district, Dong Thap province. The samples were packed and stored in an insulated box containing crushed ice at $4^{\circ} \mathrm{C}$. The samples were transferred quickly within $24 \mathrm{~h}$ to the laboratory of the Department of Veterinary Medicine, College of Agriculture, Can Tho University for further processing.

Water samples: All bottles and jars of sampling were thoroughly cleaned before being coated at least three times with the water sampled. The sterile glass bottles held around 250-300 mL of water. After that, the containers were carefully sealed with lids and refrigerated before being transported to the laboratory for isolating [7].

Sludge samples: The bottom sludge sample was collected using polyvinyl chloride pipes that had been disinfected with $70 \%$ alcohol. Sludge samples were taken from three locations: the beginning of the pond, the middle of the pond, and the pond end along a diagonal. At each site, approximately $100 \mathrm{~g}$ of sludge was collected [8].

Fish tissues samples: samples from striped catfish with typical symptoms such as hemorrhagic spots in the fin area, enlarged head, and abdomen were collected. Five to six infected fish were collected from each pond and stored on ice before being transported to the laboratory for further handling. The fish body was disinfected with $70^{\circ} \mathrm{C}$ alcohol and then cut with sterilized scalpels and scissors. Extra pathological signs of fish were also recorded, and the organs were then collected and ground for phage isolation [9].
Bacteriophage isolation capable of lysing A. hydrophila (ATCC® $7966^{\mathrm{TM}}$ )

The bacteriophages were isolated according to the method of Kropinski., et al. [10]. Each sample (1 g or $1 \mathrm{~mL}$ ) was mixed with $10 \mathrm{~mL}$ of TSB (tryptone soy broth) and incubated at $28^{\circ} \mathrm{C}$ for $24 \mathrm{~h}$. After $24 \mathrm{~h}$, the growth solution was supplemented with chloroform followed by incubation for 2 hours and centrifugation at $6000 \mathrm{rpm}$ at $4{ }^{\circ} \mathrm{C}$ for $15 \mathrm{~min}$. Bacteria A. hydrophila $\left(\right.$ ATCC $^{\circledR} 7966^{\mathrm{TM}}$ ) was used as the host to determine the presence of bacteriophages. In addition, the presence of phage was determined when plaque appeared on the surface of TSB $+0.6 \%$ agar plates containing $A$. hydrophila bacteria. The isolated bacteriophages were stored in $50 \%$ glycerol at $-80^{\circ} \mathrm{C}$.

\section{pH stability test}

The viability of bacteriophages at different $\mathrm{pH}$ was determined based on the study Verma., et al. [11] and Xuan., et al. [12]. The $\mathrm{pH}$ of the TSB medium was adjusted using either $1 \mathrm{M} \mathrm{HCl}$ or $1 \mathrm{M}$ $\mathrm{NaOH}$ to attain a solution with pH levels $2,3,4,5,6,7,8,9$, and 10 . A total of $0.1 \mathrm{~mL}$ bacteriophage suspension at a concentration of $10^{8} \mathrm{PFU} / \mathrm{mL}$ or $10^{9} \mathrm{PFU} / \mathrm{mL}$ were mixed with $1 \mathrm{~mL}$ of TSB and incubated at $28^{\circ} \mathrm{C}$ for $24 \mathrm{~h}$. After incubation, the growth solution was supplemented with chloroform (incubated for $2 \mathrm{~h}$ ) and centrifuged at $6000 \mathrm{rpm}$ at $4^{\circ} \mathrm{C}$ for $15 \mathrm{~min}$. The viability of bacteriophages on the surface of $\mathrm{TSB}+0.6 \%$ agar plates containing $A$. hydrophila bacteria was tested. Bacteriophage suspension maintained at $\mathrm{pH} 7$ was used as a control. Each pH test was conducted in triplicate.

\section{Temperature stability test}

Screening the viability of bacteriophages was carried out using the methods described by Easwaran., et al. [4] and Xuan., et al. [12] at different temperatures of $4^{\circ} \mathrm{C}, 20^{\circ} \mathrm{C}, 60^{\circ} \mathrm{C}, 80^{\circ} \mathrm{C}, 100^{\circ} \mathrm{C}$, and $120^{\circ} \mathrm{C}$. The phage suspensions (concentrations $10^{8} \mathrm{PFU} / \mathrm{mL}$ or $10^{9} \mathrm{PFU} /$ $\mathrm{mL}$ ) were incubated at the respective temperatures for $1 \mathrm{~h}$. Later, the viability test of the bacteriophages on the surface of TSB+0.6\% agar plates containing $A$. hydrophila bacteria was performed. Each temperature treatment was conducted in triplicate.

Evaluation of bacteriophages capable of lysing A. hydrophila in water

Six bacteriophages were selected to lyse $A$. hydrophila (ATCC $^{\circledR}$ $7966^{\mathrm{TM}}$ ) in tap and river water samples. Two experiments were conducted, in which tap and river water was used in experiment 
Isolation and Characterization of Bacteriophages Against Aeromonas hydrophila Bacteria Causing Hemorrhagic Septicemia from Striped Catfish (Pangasianodon hypophthalmus)

1 and experiment 2, respectively. There were three treatments in each experiment. They included treatment 1-only bacteria, treatment 2-only bacteriophages, and treatment 3-both bacteria and bacteriophages. The experiments were conducted in 21-day test with triplicate in aquariums without fish to observe the interaction of $A$. hydrophila (ATCC ${ }^{\circledR} 7966^{\mathrm{TM}}$ ) and the bacteriophage. All water samples were autoclaved at $121^{\circ} \mathrm{C}$ for 15 minutes.

For the first experiment, $1 \mathrm{~L}$ of tap water was added to each aquarium. In treatment $1,0.7 \mathrm{~mL}$ of bacteriophage culture $24 \mathrm{~h}$ $\left(10^{8} \mathrm{CFU} / \mathrm{mL}\right)$ was added to each aquarium. In treatment $2,0.7 \mathrm{~mL}$ of a bacteriophage $\left(10^{9}-10^{10} \mathrm{PFU} / \mathrm{mL}\right)$ was added to each aquarium. For treatment 3 , bacteria and bacteriophages were added as above to each aquarium. The bacteria and bacteriophage were detected daily by colony and plaque count method. For the second experiment, the river water experiment was conducted like the first experiment and maintained at room temperature [13]. Bacterial counts were measured per day at $\mathrm{OD}=600 \mathrm{~nm}$ and bacteriophage density.

\section{Phage density}

The concentration of phages was diluted by adding $0.1 \mathrm{~mL}$ of each phage solution into sterile Eppendorf containing $0.9 \mathrm{~mL}$ of distilled water, then shaking to homogenize the mixture. This step was repeated until the phage concentration reached $10^{-5}$. Then, 0.1 $\mathrm{mL}$ of each diluted phage was spread on each sterile Petri dish together with $0.1 \mathrm{ml}$ of $A$. hydrophila host bacteria suspension $\left(10^{8}\right.$ CFU/mL). About 10-12 mL TSB medium with $0.6 \%$ agar were added, melted, and let cool in waterbath at $50^{\circ} \mathrm{C}$ for at least 30 minutes. The dish was shaken to homogenize the mixture, then let still until the agar cooled down at $37^{\circ} \mathrm{C}$ for 24 hours. After 24 hours, plaques were observed and counted [14].

The phage density was calculated using the following formula [15]: $\mathrm{PFU} / \mathrm{mL}=\mathrm{N} \times 1 / \mathrm{DF} \times 1 / \mathrm{V}$, in which: $\mathrm{N}$ is the number of countable melt; $\mathrm{DF}$ is the dilution factor; $\mathrm{V}$ is the phage volume $(\mathrm{mL})$.

\section{Results}

\section{Isolation of bacteriophages}

From a total of 110 samples, 64 bacteriophages were isolated (58.2\%) with the potential of lysing A. hydrophila bacteria (Table 1). Among them, 17 bacteriophages (56.7\%) were isolated from water, and 11 bacteriophages (100\%) were isolated from sludge samples. For striped catfish visceral samples, the percentages of isolated bacteriophages ranged from $43.5 \%$ to $65.2 \%$, with the highest being in the intestine.

\begin{tabular}{|l|c|c|c|}
\hline $\begin{array}{l}\text { Type of } \\
\text { sample }\end{array}$ & No. of samples & $\begin{array}{c}\text { No. of bacteriophages } \\
(\mathbf{+}\end{array}$ & $\begin{array}{c}\text { Percentage } \\
\text { (\%) }\end{array}$ \\
\hline Water & 30 & 17 & 56.7 \\
\hline Sludge & 11 & 11 & 100 \\
\hline Intestine & 23 & 15 & 65.2 \\
\hline Liver & 23 & 11 & 47.8 \\
\hline Kidney & 23 & 10 & 43.5 \\
\hline Total & 110 & 64 & 58.2 \\
\hline
\end{tabular}

Table 1: The result of bacteriophage isolation.

\section{Effects of pH on bacteriophage stability}

The changes in bacteriophage viability under the influence of different $\mathrm{pH}$ conditions are shown in table 2 . It gradually increased from acidic to neutral conditions ( $\mathrm{pH} 2$ to $\mathrm{pH} 7$ ) and slightly decreased from neutral to alkaline or strongly alkaline conditions ( $\mathrm{pH} 7$ to $\mathrm{pH} 10$ ). In detail, 39/64 bacteriophages survived at $\mathrm{pH} 5$; $50 / 64$ bacteriophages at $\mathrm{pH} 6 ; 64 / 64$ bacteriophages at $\mathrm{pH} 7$ and $51 / 64$ bacteriophages at $\mathrm{pH} 8$, which accounted for $60.9 \%, 78.1 \%$, $100 \%$ and $79.7 \%$, respectively. At the lowest and highest $\mathrm{pH}$ values (pH 2 and pH 10), fewer percentages of bacteriophages could survive $(18.8 \%$ and $10.9 \%$, respectively).

\begin{tabular}{|l|c|c|c|c|c|c|c|c|c|c|}
\hline \multirow{2}{*}{$\begin{array}{l}\text { Type of sample } \\
2\end{array}$} & $\mathbf{3}$ & $\mathbf{4}$ & $\mathbf{5}$ & $\mathbf{6}$ & $\mathbf{7}$ & $\mathbf{8}$ & $\mathbf{9}$ & $\mathbf{1 0}$ & \\
\cline { 2 - 12 } $\begin{array}{l}\text { Water } \\
(\mathrm{n}=17)\end{array}$ & $\begin{array}{c}\text { No. of phages } \\
(+)\end{array}$ & 6 & 6 & 7 & 12 & 15 & 17 & 15 & 9 & 6 \\
\cline { 2 - 11 } & $\begin{array}{c}\text { Percentage } \\
(\%)\end{array}$ & 35.3 & 35.3 & 41.2 & 70.6 & 88.2 & 100 & 88.2 & 52.9 & 35.3 \\
\hline $\begin{array}{l}\text { Sludge } \\
(\mathrm{n}=11)\end{array}$ & $\begin{array}{c}\text { No. of phages } \\
(+)\end{array}$ & 1 & 1 & 2 & 3 & 7 & 11 & 7 & 3 & 1 \\
\cline { 2 - 11 } & $\begin{array}{c}\text { Percentage } \\
(\%)\end{array}$ & 9.09 & 9.09 & 18.2 & 27.3 & 63.6 & 100 & 63.6 & 27.3 & 9.09 \\
\hline $\begin{array}{l}\text { Intestine } \\
(\mathrm{n}=15)\end{array}$ & $\begin{array}{c}\text { No. of phages } \\
(+)\end{array}$ & 3 & 4 & 6 & 10 & 11 & 15 & 12 & 5 & 0 \\
\cline { 2 - 11 } & $\begin{array}{c}\text { Percentage } \\
(\%)\end{array}$ & 20 & 26.7 & 40 & 66.7 & 73.3 & 100 & 80 & 33.3 & 0 \\
\hline
\end{tabular}


Isolation and Characterization of Bacteriophages Against Aeromonas hydrophila Bacteria Causing Hemorrhagic Septicemia from Striped Catfish (Pangasianodon hypophthalmus)

\begin{tabular}{|l|c|c|c|c|c|c|c|c|c|c|}
\hline $\begin{array}{l}\text { Liver } \\
(\mathrm{n}=11)\end{array}$ & $\begin{array}{c}\text { No. of phages } \\
(+)\end{array}$ & 1 & 1 & 3 & 8 & 9 & 11 & 9 & 2 & 0 \\
\cline { 2 - 11 } & $\begin{array}{c}\text { Percentage } \\
(\%)\end{array}$ & 9.09 & 9.09 & 27.3 & 72.7 & 81.8 & 100 & 81.8 & 18.2 & 0 \\
\hline $\begin{array}{l}\text { Kidney } \\
(\mathrm{n}=10)\end{array}$ & $\begin{array}{c}\text { No. of phages } \\
(+)\end{array}$ & 1 & 2 & 4 & 6 & 8 & 10 & 8 & 2 & 0 \\
\cline { 2 - 11 } & $\begin{array}{c}\text { Percentage } \\
(\%)\end{array}$ & 10 & 20 & 40 & 60 & 80 & 100 & 80 & 20 & 0 \\
\hline $\begin{array}{l}\text { Total } \\
(\mathrm{n}=64)\end{array}$ & $\begin{array}{c}\text { No. of phages } \\
(+)\end{array}$ & 12 & 14 & 22 & 39 & 50 & 64 & 51 & 21 & 7 \\
\cline { 2 - 11 } & $\begin{array}{c}\text { Percentage } \\
(\%)\end{array}$ & 18.8 & 21.9 & 34.4 & 60.9 & 78.1 & 100 & 79.7 & 32.8 & 10.9 \\
\hline
\end{tabular}

Table 2: Stability of bacteriophage incubated at various pHs.

\section{Effects of temperature on bacteriophage stability}

Table 3 shows that bacteriophages had a high ability to survive in a wide range of temperature conditions (from $4^{\circ} \mathrm{C}$ to $120^{\circ} \mathrm{C}$ ) within one hour, with a more than $50 \%$ survival rate. No effects of temperature at $4^{\circ} \mathrm{C}$ and $20^{\circ} \mathrm{C}$ on the stability of bacteriophage were found. At temperatures of $60^{\circ} \mathrm{C}, 80^{\circ} \mathrm{C}, 100^{\circ} \mathrm{C}$, and $120^{\circ} \mathrm{C}$, the adaptation of bacteriophages gradually decreased with the corresponding rate of $89.1 \%, 71.9 \%, 57.8 \%$, and $51.6 \%$.

\begin{tabular}{|c|c|c|c|c|c|c|c|}
\hline \multirow{2}{*}{\multicolumn{2}{|c|}{ Type of sample 4}} & \multicolumn{6}{|c|}{ Temperature $\left({ }^{\circ} \mathrm{C}\right)$} \\
\hline & & 20 & 60 & 80 & 100 & 120 & \\
\hline \multirow{2}{*}{$\begin{array}{l}\text { Water } \\
(n=17)\end{array}$} & No. of phages $(+)$ & 17 & 17 & 14 & 13 & 12 & 12 \\
\hline & Perc & 100 & 100 & 82.4 & 76.5 & 70.6 & 70.6 \\
\hline \multirow{2}{*}{$\begin{array}{l}\text { Sludge } \\
(n=11)\end{array}$} & No. of phages (+) & 11 & 11 & 10 & 9 & 7 & 7 \\
\hline & e $(\%)$ & 100 & 100 & 90.9 & 81.8 & 63.6 & 63.6 \\
\hline \multirow{2}{*}{$\begin{array}{l}\text { Intestine } \\
(n=15)\end{array}$} & No. of phages $(+)$ & 15 & 13 & 14 & 11 & 10 & 9 \\
\hline & Percentage (\%) & 100 & 100 & 93.3 & 73.3 & 66.7 & 60 \\
\hline \multirow{2}{*}{$\begin{array}{l}\text { Liver } \\
(n=11)\end{array}$} & $(+)$ & 11 & 1 & 9 & 8 & 5 & 2 \\
\hline & Percentage (\%) & 100 & 100 & 81.8 & 72.7 & 45.5 & 18.2 \\
\hline \multirow{2}{*}{$\begin{array}{l}\text { Kidney } \\
(n=10)\end{array}$} & No. of phages $(+)$ & 10 & 10 & 10 & 5 & 3 & 3 \\
\hline & $(\%)$ & 100 & 100 & 100 & 50 & 30 & 30 \\
\hline \multirow{2}{*}{$\begin{array}{l}\text { Total } \\
(n=64)\end{array}$} & No. of phages $(+)$ & 64 & 6 & 57 & 46 & 37 & 33 \\
\hline & Percentage (\%) & 100 & 100 & 89.1 & 71.9 & 57.8 & 51.6 \\
\hline
\end{tabular}

Table 3: Stability of bacteriophage incubated at various temperatures.
Evaluation of bacteriophages capable of lysing A. hydrophila in water

Through the investigation of the survival in different $\mathrm{pH}$ (2-10) and temperature $\left(4,20,60,80,100,120^{\circ} \mathrm{C}\right)$ conditions of 64 bacteriophages, six bacteriophages were selected to test the survival ability in tap water and river water conditions for 21 days. These bacteriophages were B.N26, B.N16, B.R18, B.B8, B.R22, and B.N1.

\section{Bacteria density over 21 days in tap and river water}

In tap and river water without bacteriophages, the bacterial density of $A$. hydrophia bacteria increased or decreased over time, as shown in figure 1 . The results show that the bacterial density in both tap water and river water was of an upward trend from the $1^{\text {st }}$ to $5^{\text {th }}$ day and gradually decreased to the $21^{\text {st }}$ of the experiment (Figure 1). Specifically, on the first day, the bacterial density in the tap water was $6.74 \log _{10} \mathrm{CFU} / \mathrm{mL}$ and river water $7.08 \log _{10} \mathrm{CFU} /$ $\mathrm{mL}$. On the $5^{\text {th }}$ day, the bacterial density in the tap water increased by $7.16 \log _{10} \mathrm{CFU} / \mathrm{mL}$, and the bacterial density in the river water was $7.58 \log _{10} \mathrm{CFU} / \mathrm{mL}$. However, on the following days, the bacterial density in tap and river water started to drop until the $21^{\text {st }}$ day. Yet, the bacterial density in the tap water experienced a more considerable decline than in the river water. On the $21^{\text {st }}$ day of the study, the bacterial density in the tap water and river water fell at the rate of $3.30 \log _{10} \mathrm{CFU} / \mathrm{mL}$ and $5.10 \log _{10} \mathrm{CFU} / \mathrm{mL}$, respectively.

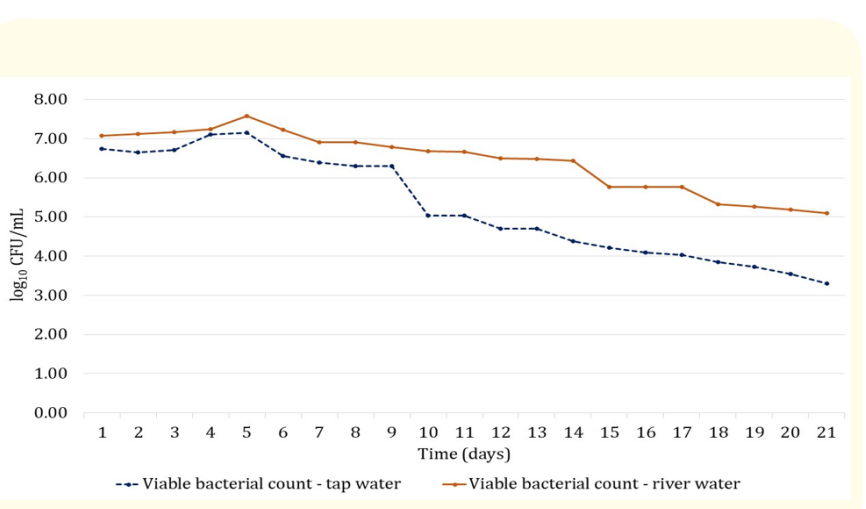

Figure 1: Bacteria density in tap water and river water over 21 days. 
Isolation and Characterization of Bacteriophages Against Aeromonas hydrophila Bacteria Causing Hemorrhagic Septicemia from Striped Catfish (Pangasianodon hypophthalmus)

Determination of bacteriophage density over 21 days in tap water and river water

In the tap and river water with bacteriophages, the bacteriophage density was tended to decrease gradually over 21 days of the experiment (Figure 2). Specifically, bacteriophage density on $1^{\text {st }}$ day of tap water was $10.8 \log _{10} \mathrm{PFU} / \mathrm{mL}$ and that of river water 10.8 $\log _{10} \mathrm{PFU} / \mathrm{mL}$. Next, both started to go down slightly from the $2^{\text {nd }}$ to the $4^{\text {th }}$ day, to hit $10.7 \log _{10} P F U / m L$ for the bacteriophage density in river water and $9.84 \log _{10} \mathrm{PFU} / \mathrm{mL}$ for the bacteriophage density in tap water. In the following days until the $21^{\text {st }}$, the bacteriophage density witnessed a plunge, registering $4.17 \log _{10} \mathrm{PFU} / \mathrm{mL}$ for the former and $3.13 \log _{10} \mathrm{PFU} / \mathrm{mL}$ for the latter.

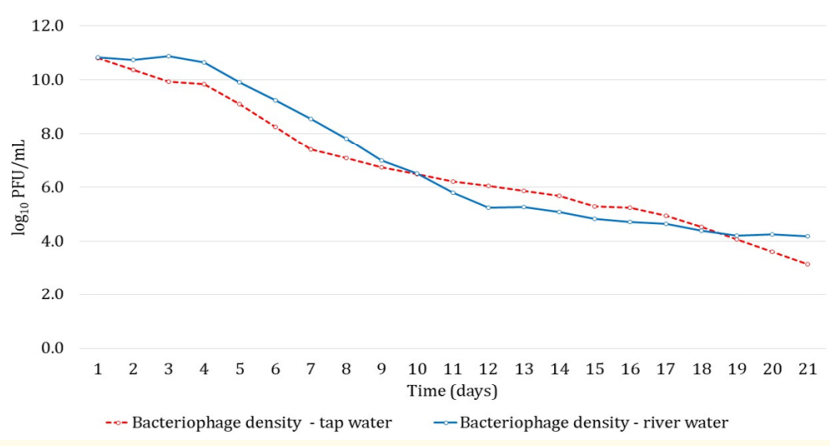

Figure 2: Bacteriophage density in clean water and river water over 21 days.

Determination of bacteria and bacteriophage density over 21 days in tap and river water

The results of figure 3 show that the density of bacteriophages and bacteria in tap and river water tended to decrease over the 21 days. The bacteriophage density in river water and tap water tended to increase early and drop later. Specifically, the former rose from the $1^{\text {st }}$ to $8^{\text {th }}$ day (from $10.6 \log _{10}$ PFU/mL to $13.8 \log _{10}$ PFU/ $\mathrm{mL}$ ), and then it fell until the $21^{\text {st }}$ day (down to $9.12 \log _{10} \mathrm{PFU} / \mathrm{mL}$ ). Similarly, the increase from the $1^{\text {st }}$ to $7^{\text {th }}$ day from $10.6 \log _{10} P F U /$ $\mathrm{mL}$ to $10.7 \log _{10} \mathrm{PFU} / \mathrm{mL}$, after which it registered a drop until the $21^{\text {st }}$ day (reduced to $5.13 \log _{10} \mathrm{PFU} / \mathrm{mL}$ ).

Concerning bacteria, the densities in tap water and river water were unstable early and decreased later. Notably, the bacterial density in the river water fluctuated from the $1^{\text {st }}$ to the $5^{\text {th }}$ day with an overall upward trend (from $6.61 \log _{10} \mathrm{CFU} / \mathrm{mL}$ to $7.56 \log _{10} \mathrm{CFU} /$

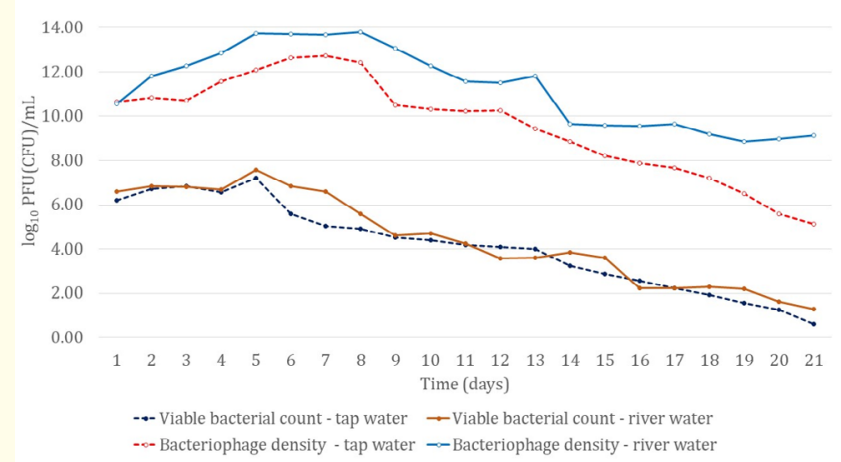

Figure 3: Bacteria and bacteriophage density in ctap water and river water over 21 days.

$\mathrm{mL}$ ). By the $21^{\text {st }}$ day, it fell to $1.30 \log _{10} \mathrm{CFU} / \mathrm{mL}$. Likewise, the bacterial density in tap water from the 1 st to 5 th day was seen, yet generally, it rose from $6.21 \log _{10} \mathrm{CFU} / \mathrm{mL}$ to $7.19 \log _{10} \mathrm{CFU} / \mathrm{mL}$. After that, the figure was reduced to $0.63 \log _{10} \mathrm{CFU} / \mathrm{mL}$ on the $21^{\text {st }}$ day.

The density of six bacteriophages over 21 days in tap water and river water

The density of six bacteriophages (B.N26, B.N16, B.R18, B.B8, B.R22, B.N1) and A. hydrophila (ATCC ${ }^{\circledR} 7966^{\mathrm{TM}}$ ) in tap and river water are shown in figure 4 and figure 5 . For the tap water environment (Figure 4), the density of both six bacteriophages and bacteria experienced a downward trend. Still, the density of six bacteriophages increased from the $1^{\text {st }}$ to the $7^{\text {th }}$ day before seeing a fall to the $21^{\text {st }}$ day. The figure for bacteriophages rose from 10.5-10.8 to $12.5-12.9 \log _{10} \mathrm{PFU} / \mathrm{mL}$, after which it went down to $4.98-5.22$ $\log _{10} \mathrm{PFU} / \mathrm{mL}$ while that of bacteria decreased from 6.00-6.51 to 0.60-0.66 $\log _{10} \mathrm{CFU} / \mathrm{mL}$ over 21 days.

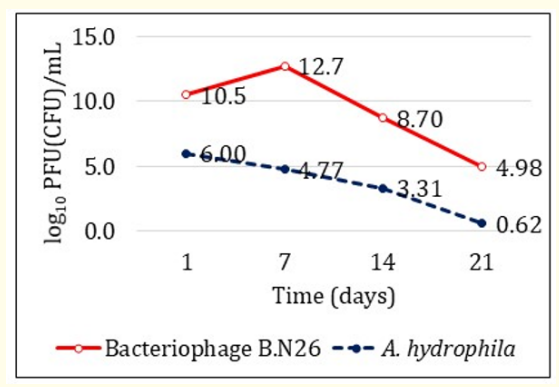

(a) 


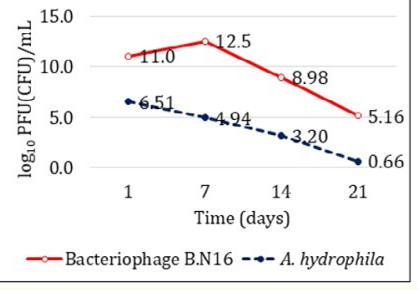

(b)

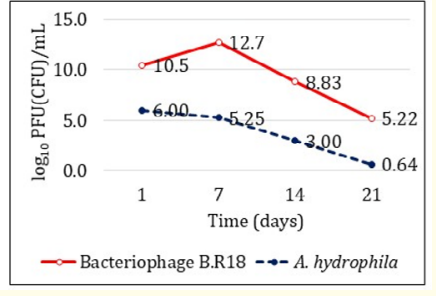

(c)

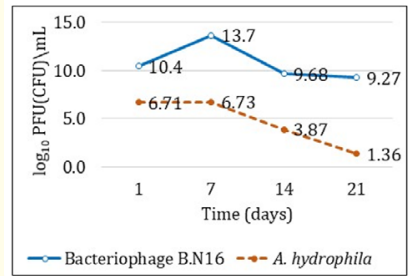

(b)

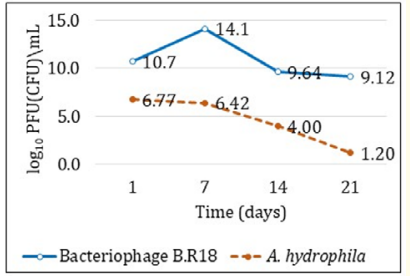

(c)

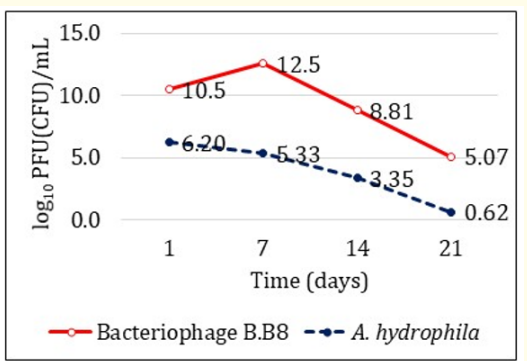

(d)

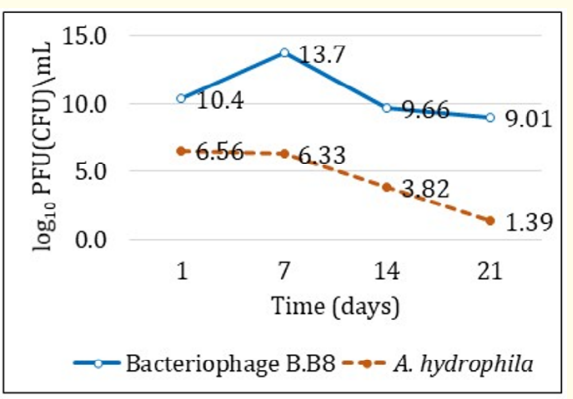

(d)

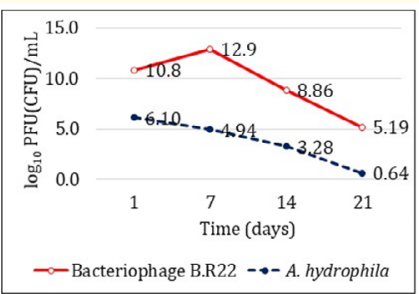

(e)

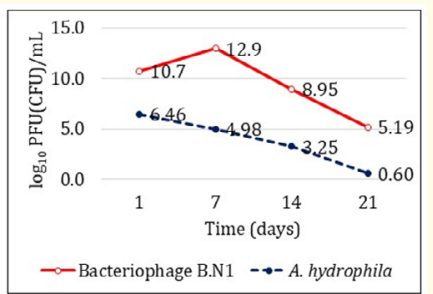

(f)
Figure 4: Bacteria and bacteriophage density in tap water over 21 days.

(a) Bacteriophage B.N26 and bacteria A. hydrophila; (b) Bacteriophage B.N16 and bacteria A. hydrophila; (c) Bacteriophage B.R18 and bacteria A. hydrophila; (d) Bacteriophage B.B8 and bacteria A. hydrophila; (e) Bacteriophage B.R22 and bacteria A. hydrophila; (f) Bacteriophage B.N1 and bacteria A. hydrophila.

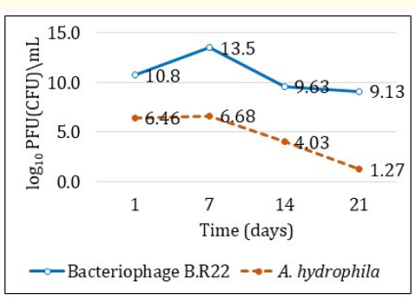

(e)

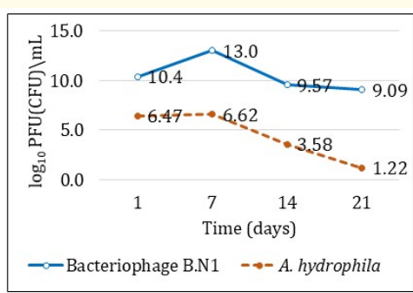

(f)
Figure 5: Bacteria and bacteriophage density in river water over 21 days.

(a) Bacteriophage B.N26 and bacteria A. hydrophila; (b) Bacteriophage B.N16 and bacteria A. hydrophila; (c) Bacteriophage B.R18 and bacteria A. hydrophila; (d) Bacteriophage B.B8 and bacteria A. hydrophila; (e) Bacteriophage B.R22 and bacteria A. hydrophila; (f) Bacteriophage B.N1 and bacteria A. hydrophila.

For the river water environment, it is shown in figure 5 that there was a drop in the density of both six bacteriophages and bacteria. However, the density of six bacteriophages increased from the $1^{\text {st }}$ to the $7^{\text {th }}$ day. It then decreased to the $21^{\text {st }}$ while the bacterial density used by bacteriophages B.N26, B.N16, B.R22, and B.N1 rose slightly in the first seven days and then dropped until the end. By contrast, the bacterial density lysed by B.R18 and B.B8 decreased over 21 days. Specifically, from day 1 to 7 , the density of six bacteriophages grew from 10.4-10.8 to $13.0-14.1 \log _{10} \mathrm{PFU} / \mathrm{mL}$ and then 
fell to 9.01-9.27 $\left.\log _{10} P F U / m L\right)$. The bacterial density lysed by bacteriophages B.N26, B.N16, B.R22, and B.N1 increased slightly from the $1^{\text {st }}$ to the $7^{\text {th }}$ day $\left(6.46-6.71\right.$ to $\left.6.62-6.76 \log _{10} \mathrm{CFU} / \mathrm{mL}\right)$ and then decreased to the $21^{\text {st }}$ day (to $1.22-1.36 \log _{10} \mathrm{CFU} / \mathrm{mL}$ ). The bacterial density lysed by B.R18 and B.B8 decreased (from 6.56-6.77 $\log _{10}$ CFU/mL to $1.20-1.39 \log _{10} \mathrm{CFU} / \mathrm{mL}$ ).

\section{Discussion}

\section{Isolation of bacteriophages}

The results of the current work showed that 64 bacteriophages were isolated from water, sludge, and internal organs of a striped catfish farm. This indicated the existence of bacteriophages, as indicated by many authors. According to Jończyk., et al. [16], bacteriophages are detected in ground and surface water, soil, food (e.g., sauerkraut, wine), sewage, and sludge. Particularly, in the environment where bacteria exist, the probability of finding the desired bacteriophages is very high. In addition, Hyman [17] reported that not all bacteria are hosts of bacteriophages, and not all bacteriophages have the ability to lyse bacteria; phages are temperate bacteriophages. In 2020, Park., et al. [18] suggested that bacteriophages are the most abundant living entities on earth, and they play significant roles in bacterial ecology, adaptation, evolution, and pathogenesis. Bacteriophages are common in soils (approximately $10^{7}$ to $10^{9}$ virions/g) and highly abundant in freshwater and marine ecosystems (about $10^{7}$ virions $/ \mathrm{ml}$ ), and their total number on earth was estimated at $10^{31}$ virions.

\section{pH stability of bacteriophages}

The various external physical and chemical factors as temperature, acidity, salinity, and ions, determine the occurrence, viability, and storage of bacteriophages. These factors can inactivate a phage through damage of its structural elements (head, tail, envelope), lipid loss, and/or DNA structural changes [19]. In this study, striped catfish were relatively vulnerable to pond water conditions. Two of the most key parameters were temperature and $\mathrm{pH}$, with the suitable values range in pond water for striped catfish being 25$32^{\circ} \mathrm{C}$ and 5.5-9 [12]. In addition, according to Watanabe., et al. [20], gastric acid can negatively affect phage survival. Therefore, the present study was conducted to research the viability and selection of bacteriophages capable of lysing $A$. hydrophila from pH (2-10) to treat hemorrhagic disease on striped catfish. Easwaran., et al. [4] reported that phages are stable under different $\mathrm{pH}$ (1-13) and optimum $\mathrm{pH}$ of pAh-1 as 7.5 (1-h incubation at $28^{\circ} \mathrm{C}$ ). The pAh- 1 was unstable at highly acidic ( $\leq \mathrm{pH} 3$ ) levels accounting for under $20 \%$ as equally as phages isolated in the present report at highly acidic ( $\leq \mathrm{pH} 3$ ), accounting for about $20 \%$. However, pH 5-11 showed more stable pAh-1 (>90\%) and was higher than in the present study. Similarly, Chandrarathna., et al. [21] indicated that bacteriophages are active at $\mathrm{pH}$ 4-10 (about $80 \%$ ) but inactive in highly acidic conditions $(<\mathrm{pH} 4)$ and highly alkaline conditions ( $>\mathrm{pH} 10)$.

On the other hand, Gwak., et al. [22] indicated that KFS-YE isolated a lytic Yersinia enterocolitica-specific phage (KFS-YE) was stable at wide ranges of $\mathrm{pH}$ (4-11). According to Ma., et al. [23] and Ramirez., et al. [24], the bacteriophages can survive at low pH due to form microencapsulation. These encapsulation-forming bacteriophages maintained higher bacteria lysing-ability than did non-encapsulated phages in the $\mathrm{pH}$ range (3-7). Besides, Colom., et al. [25] recently demonstrated that encapsulation (alginate/CaCO3) could protect the bacteriophages against their destruction by the gastric juice, the low stomach $\mathrm{pH}$, and the activities of bile and intestinal tract enzymes limit the efficacy of the phages.

\section{Temperature stability of bacteriophages}

Temperature is a crucial factor for bacteriophage survivability. It plays a fundamental role in attachment, penetration, multiplication, and the length of the latent period (in the case of lysogenic phages). At lower than optimal temperatures, fewer phage genetic materials penetrate bacterial host cells; therefore, fewer of them can be involved in the multiplication phase. Higher temperatures can prolong the length of the latent stage. Moreover, temperature determines the occurrence, viability, and storage of bacteriophages [16]. In the study of Liu., et al. [26], the five bacteriophages (W3, G65, Y81, N21, Y71) maintained almost 100\% infectivity after being cultured at $4^{\circ} \mathrm{C}$ or $30^{\circ} \mathrm{C}$ for 1 day and remained relatively stable at $30^{\circ} \mathrm{C}$ and $40^{\circ} \mathrm{C}$, but sensitive to higher temperatures. No more than $50 \%$ of phages remained alive after a 40 -min incubation at $50^{\circ} \mathrm{C}$. At $60^{\circ} \mathrm{C}$, less than $1 \%$ of phages W3, G65, and Y81 survived for $20 \mathrm{~min}$, and phages N21 and Y71 for $40 \mathrm{~min}$. Besides, according to Easwaran., et al. [4], thermal stability results demonstrated that phage titer did not reduce when pAh-1 was incubated at 4,20 , and $40^{\circ} \mathrm{C}$ for $1 \mathrm{~h}$. However, pAh- 1 titre was significantly reduced at $60^{\circ} \mathrm{C}$ $(18.9 \%), 80^{\circ} \mathrm{C}(97.2 \%)$ and $100^{\circ} \mathrm{C}(98.1 \%)$ at a specific temperature for $1 \mathrm{~h}$. Similarly, Xuan., et al. [12] investigated the thermal stability of bacteriophages against mass mortality of the striped catfish caused by A. hydrophila. The authors also showed that the activity of TG25P retained to approximately $90 \%$ and $80 \%$ at $37^{\circ} \mathrm{C}$ and $50^{\circ} \mathrm{C}$ for $1 \mathrm{~h}$, respectively. 
Knowledge of phage stability is necessary when phages are subjected to industrial processes such as manufacturing medicated feed, where high temperatures and different pH are often used [21]. In 2018, Le., et al. [6] suggested that the survival of phages, together with their persistent survival on or in fish and phage-coated feed preparations, should be studied under different environmental factors (e.g., temperature, salt concentration) to determine whether phages can persist and effectively reduce Aeromonas spp. levels in fish farms. Additionally, Malik [27] showed that exploiting the potential of bacteriophages for phage therapy is an exciting prospect. However, to be successful, there is a pressing need for the safe manufacture and efficacious phage drug products to treat patients. The scalable manufacture of phage biologics as a stable solid dry powder form is highly desirable and achievable using spray drying. The process allows control over the final phage dose in the powder and the production of microparticles suitable for therapeutic uses. The activity of the phages in spray-dried powders is adversely affected during spray drying, and this is also an essential factor affecting the stability of the bacteriophages in the dry powder form.

Evaluation of bacteriophages capable of lysing $A$. hydrophila in water

The success of phage therapy to control fish pathogenic bacteria depends on viral survival and viability in culture water of fish-farming plants. Although there are some available data on the mechanisms and rates of mortality or loss of infectivity of phages in marine waters, little is known about their survival time in the marine environment [2].

Identification of bacteria density over 21 days in tap water and river water

The results of this study in the river water were higher than those of Imbeault., et al. [13] when comparing the viability of bacteria in open water and lower than the research of Imbeault., et al. [13] when investigating the viability of bacteria in interstitial water over 21 days. According to Imbeault., et al. [13], in open water, $A$. salmonicida concentration increased from $10^{7} \mathrm{CFU} / \mathrm{mL}$ to $10^{9} \mathrm{CFU} /$ $\mathrm{mL}$ by two log units until day 8 . It then decreased progressively to below detection level $\left(5 \times 10^{1} \mathrm{CFU} / \mathrm{mL}\right)$ on day 16 . In interstitial water, A. salmonicida concentration rose by four log units (from $10^{7}$ $\mathrm{CFU} / \mathrm{mL}$ to $10^{11} \mathrm{CFU} / \mathrm{mL}$ ) between days 4 and 11 and then dropped slightly until day $15\left(10^{10} \mathrm{CFU} / \mathrm{mL}\right)$, when a considerable increase in bacterial flora made $A$. salmonicida counts impossible.
Identification of bacteriophage density over 21 days in tap water and river water

In this work, parameters in the river water were similar to that of Imbeault., et al. [13]. The results showed that in aquariums with phages but no A. salmonicida, bacteriophages HER 110 decreased in number over time. However, HER 110 phage density in open water reduced less, and HER 110 phage density in interstitial water dropped more than in the present study. Their density fell below detection $\left(2 \times 10^{2} \mathrm{PFU} / \mathrm{mL}\right)$ in open water on day 11 but remained constant at $500 \mathrm{PFU} / \mathrm{mL}$ in interstitial water between days 14 and 21.

Identification of bacteria and bacteriophage density over 21 days in tap and river water

The present study is similar to that of Imbeault., et al. [13] when using bacteriophages to prevent furunculosis caused by Aeromonas salmonicida in farmed Brook Trout. In the treatment supplied with bacteriophages and $A$. salmonicida, bacteriophage density remained high and stable throughout the test in both open and interstitial water. Bacteriophages density in interstitial water $\left(10^{12}\right.$ $\mathrm{PFU} / \mathrm{mL})$ was higher than in open water $\left(10^{9} \mathrm{PFU} / \mathrm{mL}\right)$. However, the bacterial density in the river water in this present study was higher than that in the research of Imbeault., et al. [13]. The concentration of $A$. salmonicida in open water increased to $10^{8} \mathrm{CFU} /$ $\mathrm{mL}$ before phages were added on day 4 . It decreased rapidly to $10^{3}$ $\mathrm{CFU} / \mathrm{mL}$ on day 7 and below detection level on day 13 . The concentration of $A$. salmonicida in interstitial water decreased by six log units $\left(10^{8}\right.$ to $\left.10^{2} \mathrm{CFU} / \mathrm{mL}\right)$ from day 4 to day 9 and then remained detectable but low until day 21 .

In addition, Pereira., et al. [2] reported that the pattern of bacteriophage survival in aquaculture water was different for the two bacteriophages tested. The abundance of AS- 1 phage decreased by one order of magnitude in the first 15 days and, after reaching a plateau, that value remained constant for 45 days. Afterward, the bacteriophage titer decreased slightly until 91 days. In contrast, the abundance of VP-1 phage decreased strongly during the incubation period, showing a survival period of 16 days, much lower than the AS-1 phage. In this study, the bacteriophage density was increased in the first 8 days before reducing until day 21. According to Easwaran., et al. [4], the growth of the phage was directly proportional to the concentration of $\mathrm{Ca}^{2+}$, and the divalent metal ions $\left(\mathrm{Ca}^{2+}\right.$ and $\left.\mathrm{Mg}^{2+}\right)$ can stabilize the activity of pAh-1. This characteristic is essential for applications of pAh-1 in the field level, where

Citation: Nguyen Trong Ngu., et al. "Isolation and Characterization of Bacteriophages Against Aeromonas hydrophila Bacteria Causing Hemorrhagic Septicemia from Striped Catfish (Pangasianodon hypophthalmus)". Acta Scientific Veterinary Sciences 4.3 (2022): 56-65. 
it may have varying concentrations of $\mathrm{Ca}^{2+}$ and $\mathrm{Mg}^{2+}$. That could be one of the reasons why phage density in river water was higher than in tap water.

In the present study, the bacteria density remained pretty high probably because the bacteria existed in mutant form. According to Silva., et al. [28], a fraction of the remained bacteria is phage-resistant. Still, it has been shown that virulent bacteria which become resistant to phage infection are less fit or lose their pathogenic properties. These occur mainly because the cell surface components, such as LPS and proteins, that act as receptors for phage adsorption also can act as virulence factors. Mutations in these receptors to develop resistance to the phage would reduce bacterial pathogenicity, and bacterial regrowth after phage therapy would result in few consequences.

\section{Conclusion}

The number of bacteriophages lysing A. hydrophila (ATCC ${ }^{\circledR}$ $7966^{\mathrm{TM}}$ ) isolated from 110 samples was 64 , accounting for $58.2 \%$. All isolated bacteriophages were in good adaptability at $\mathrm{pH} 5$ to $\mathrm{pH}$ 8 (more than $60 \%$ ) and $4^{\circ} \mathrm{C}$ and $20^{\circ} \mathrm{C}$ (constituting 100\%). From the results of $\mathrm{pH}$ and temperature test, six bacteriophages have been selected and they could survive in both tap and river water. A cocktail of six bacteriophages can be further used to treat hemorrhagic septicemia caused by $A$. hydrophila in striped catfish.

\section{Acknowledgment}

The authors would like to express their attitude to the Department of Veterinary Medicine, College of Agriculture, Can Tho University for facilitating the use of equipment in the Can Tho University Improvement Project VN14-P6 supported by a Japanese ODA loan.

\section{Conflict of Interest}

No financial interest or any conflict of interest exists.

\section{Bibliography}

1. Thi QVC., et al. "The current status antimicrobial resistance in Edwardsiella ictaluri and Aeromonas hydrophila cause disease on the striped catfish farmed in the Mekong Delta". Journal of Science Can Tho University 7.14 (2014).

2. Pereira C., et al. "Bacteriophages with potential for inactivation of fish pathogenic bacteria: survival, host specificity and effect on bacterial community structure". Marine Drugs 9.11 (2011): 2236-2255.
3. Jun JW., et al. "Protective effects of the Aeromonas phages pAh1-C and pAh6-C against mass mortality of the cyprinid loach (Misgurnus anguillicaudatus) caused by Aeromonas hydrophila". Aquaculture 416 (2013): 289-295.

4. Easwaran M., et al. "Characterization of bacteriophage pAh-1 and its protective effects on experimental infection of Aeromonas hydrophila in Zebrafish (Danio rerio)". Journal Fish Diseases 40.6 (2017): 841-846.

5. Akmal M., et al. "Isolation, characterization, and application of a bacteriophage infecting the fish pathogen Aeromonas hydrophila". Pathogens 9.3 (2020): 215.

6. Le TS., et al. "Protective effects of bacteriophages against Aeromonas hydrophila causing Motile Aeromonas Septicemia (MAS) in striped Catfish". Antibiotics 7.1 (2018): 16.

7. National standard TCVN 8880:2011 (ISO 19458:2006). "Water quality - Sampling for microbiological analysis".

8. Lan PTT. "Selection of Bacillus spp. with antagonistic activity against bacteria Aeromonas hydrophila cause hemorrhagic septicemia disease on striped catfish (Pangasianodon hypophthalmus)". (Master's thesis in Aquaculture, Can Tho University) (2015)

9. Huong PT. "Research on antibiotic resistance of Edwardsiella ictaluri and Aeromonas hydrophila cause disease on the striped catfish (Pangasianodon hypophthalmus)". (Master's thesis in Aquaculture, Can Tho University) (2010).

10. Kropinski AM., et al. "Enumeration of bacteriophages by double agar overlay plaque assay". Bacteriophages. Humana Press (2009): 69-76.

11. Verma V., et al. "Characterization of a T7-like lytic bacteriophage of Klebsiella pneumoniae B5055: a potential therapeutic agent". Current Microbiology 59.3 (2009): 274-281.

12. Xuan T., et al. "Stability and activity of TG25P phage in control of Aeromonas hydrophila in striped catfish pond water". Science and Technology Development Journal 21.2 (2018): 64-70.

13. Imbeault S., et al. "Using bacteriophages to prevent furunculosis caused by Aeromonas salmonicida in farmed brook trout". Journal of Aquatic Animal Health 18.3 (2006): 203-214.

14. Poxleitner M., et al. "Phage Discovery Guide. Howard Hughes Medical Institute". (2017).

15. Gonzalez-Menendez E., et al. "Comparative analysis of different preservation techniques for the storage of Staphylococcus phages aimed for the industrial development of phage-based antimicrobial products". PLoS One 13.10 (2018): e0205728. 
16. Jończyk E., et al. "The influence of external factors on bacteriophages-review”. Folia Microbiologica 56.3 (2011): 191-200.

17. Hyman P. "Phages for phage therapy: isolation, characterization, and host range breadth". Pharmaceuticals 12.1 (2019): 35 .

18. Park SY., et al. "Recent insights into Aeromonas salmonicida and its bacteriophages in aquaculture: A comprehensive review". Journal of Microbiology and Biotechnology (2020): 1443-1457.

19. Ackermann HW., et al. "Long-term bacteriophage preservation" (2004).

20. Watanabe R., et al. "Efficacy of bacteriophage therapy against gut-derived sepsis caused by Pseudomonas aeruginosa in mice". Antimicrobial Agents and Chemotherapy 51.2 (2007): 446-452.

21. Chandrarathna HPSU., et al. "Isolation and characterization of phage AHP-1 and its combined effect with chloramphenicol to control Aeromonas hydrophila". Brazilian Journal of Microbiology 51.1 (2020): 409-416.

22. Gwak KM., et al. "Isolation and characterization of a lytic and highly specific phage against Yersinia enterocolitica as a novel biocontrol agent". Journal of Microbiology and Biotechnology 28.11 (2018): 1946-1954.

23. Ma YH., et al. "Temporal distribution of encapsulated bacteriophages during passage through the chick gastrointestinal tract". Poultry Science 95.12 (2016): 2911-2920.

24. Ramirez Ka., et al. "Bacteriophage cocktail for biocontrol of Escherichia coli 0157: H7: Stability and potential allergenicity study". PLoS One 13.5 (2018): e0195023.

25. Colom J., et al. "Microencapsulation with alginate/CaCO3: A strategy for improved phage therapy". Scientific Reports 7.1 (2017): 1-10.

26. Liu J., et al. "Isolation and characterization of bacteriophages against virulent Aeromonas hydrophila". BMC Microbiology 20 (2020): 1-13.

27. Malik DJ. "Bacteriophage encapsulation using spray drying for phage therapy". Current Issues in Molecular Biology 40.1 (2021): 303-316.

28. Silva YJ., et al. "Phage therapy as an approach to prevent Vibrio anguillarum infections in fish larvae production". PloS One 9.12 (2014): e114197.

\section{Assets from publication with us}

- Prompt Acknowledgement after receiving the article

- Thorough Double blinded peer review

- Rapid Publication

- Issue of Publication Certificate

- High visibility of your Published work

Website: www.actascientific.com/

Submit Article: www.actascientific.com/submission.php

Email us: editor@actascientific.com

Contact us: +919182824667 